\title{
国土基本図の精度について
}

\section{The acwracg of thr National Large Scale Map}

まえがき 国土基本図の性格についてはすでにいる いろ議論されているので [6]ここでは省略するが, 技術的には作業形態として国土地理院から民間測量会 社に殆ど全部の工程を外注し, その結果を精密図化機 等によって検查しているのが大きな特長であろら。こ れらの検査の結果, 国土基本図の精度についてはいろ いろなデータが得られて㧍り, その一部は写真測量学 会の講演会等で発表され，またりスボンでの国際写真 測量学会にも国土地理院からの資料として発表されて いる。〔3〕4〕ここではこれらに新らしい若干のデ 一夕を加えて，区切りをつける意味で報告する次第で ある。従って一部既発表のデータと重複する所もあ る。

なお撮影については，すでに平井[1][2] 中村[5] 等に よって報告がされているのでここでは主として空中 三角測量と図化について検討することにしたい。

\section{§1. 国土基本図の規格}

念のため国土基本図の規格の概要をのべておく。た だし規格の表現や細部については多少の変更があった ので，昭和 40 年度現在のものによる。

（1）図化縮尺，1/5,000 および $1 / 2,500$

最初は $1 / 2,500$ が多かったが最近は $1 / 5,000$ が主 となりまた 1 万粁に10点の三等多角点（細部基準 点）を含んだ $1 / 2500$ 骨格図も作られるようになっ た。

（2）写真縮尺 $1 / 10,000$ および $1 / 20,000$ つまり写真 から地図への引伸倍率は 4 倍であるが, 撮影基準面 を少し高くとることが多いので実際の写真縮尺は約 10\%程小さくなっている。

(3) 空中三角測量の精度

(a) 1 コース15モデル以内（標準10モデル）

(b) 地上基準点での誤差

\begin{tabular}{|c|c|c|c|c|}
\hline & \multicolumn{2}{|c|}{ 縮尺 $1 / 2,500$} & 縮尺 & $1 / 5,000$ \\
\hline \multirow{2}{*}{$\begin{array}{l}\text { 標 } \\
\text { 高 }\end{array}$} & 中等䛊差 & $0.6 \mathrm{~m}$ & & $1.2 \mathrm{~m}$ \\
\hline & 最大誤差 & $1.0 \mathrm{~m}$ & & $2.0 \mathrm{~m}$ \\
\hline 位 & 中等誤差 & $0.5 \mathrm{~m}$ & & $0.9 \mathrm{~m}$ \\
\hline 置 & 最大誤差 & $0.8 \mathrm{~m}$ & & $1.5 \mathrm{~m}$ \\
\hline
\end{tabular}

* 国土地理院 写真測量 Vol. 5 No. 2 1966年

尾崎 幸男* 清野 五郎*
鈴木 利男*

(e) タイポイントでの較差

\begin{tabular}{|c|c|c|}
\hline 位 置 & $0.4 \mathrm{~mm}(=1.0 \mathrm{~m})$ & $0.4 \mathrm{~mm}(=2.0 \mathrm{~m})$ \\
\hline 標 & $1.0 \mathrm{~m}$ & 縮尺 $1 / 2,500$ \\
\hline 高 & $2.0 \mathrm{~m}$ & 縮尺 $1 / 5,000$ \\
\hline
\end{tabular}

（4）図化の精度

平面 位置 中等誤差 $0.7 \mathrm{~mm}$ (骨格をなす図

等高線間隔 $2 \mathrm{~m}$ 縮尺 $1 / 2,500$

$5 \mathrm{~m}$ 縮尺 $1 / 5,000$

\section{§ 2. 空中三角測量の精度}

過去数年間の空中三角測量の精度は第 1 表拈よび第 1 図のとおりである。

第 1 困 空中三角測量の精度

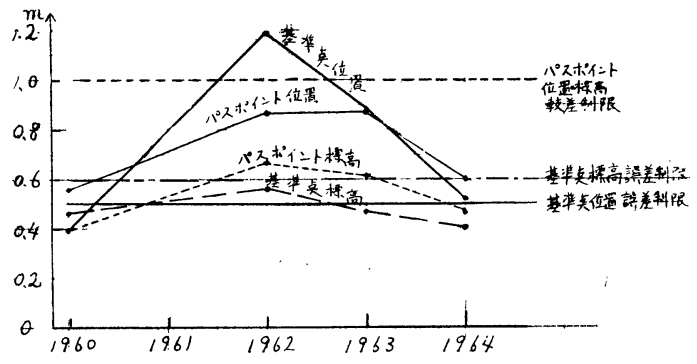

1961年度は殆ど空中三角測量や図化を実施していな いので省略してある。

この表を見れば分る通り，テストケースとして実施 された1960年度分はかなりよい精度が得られている が, 地区数, コース数も少なく, 試験作業でもあった ので，これを除外すると，精度は必ずしも香ばしくな い。第 1 表は対空標識の有無, 使用機械 (A 7 P 8 ) 作業法（機械法と解析法）の如何に拘わらない総合的 なデータであるが，前節の国土基本の規格（ただしこ れは1965年分である）には1964年分のみが辛らじて合 格しているだけである。

それも平均值が合格すれすれなのだから，個々に見 れば不合格になっている場合もかなりある筈(約30\%) である。

では国土基本図の規格がきびしすぎるのではないか との疑問が出るが，決してそうではない。最近の国際 会議やシンポジムの席上では逆にこの精度が悪すぎ て例えば1963年分の較差はこの半分程度に納まる筈な 
第 1 表 空中三角測量の精度

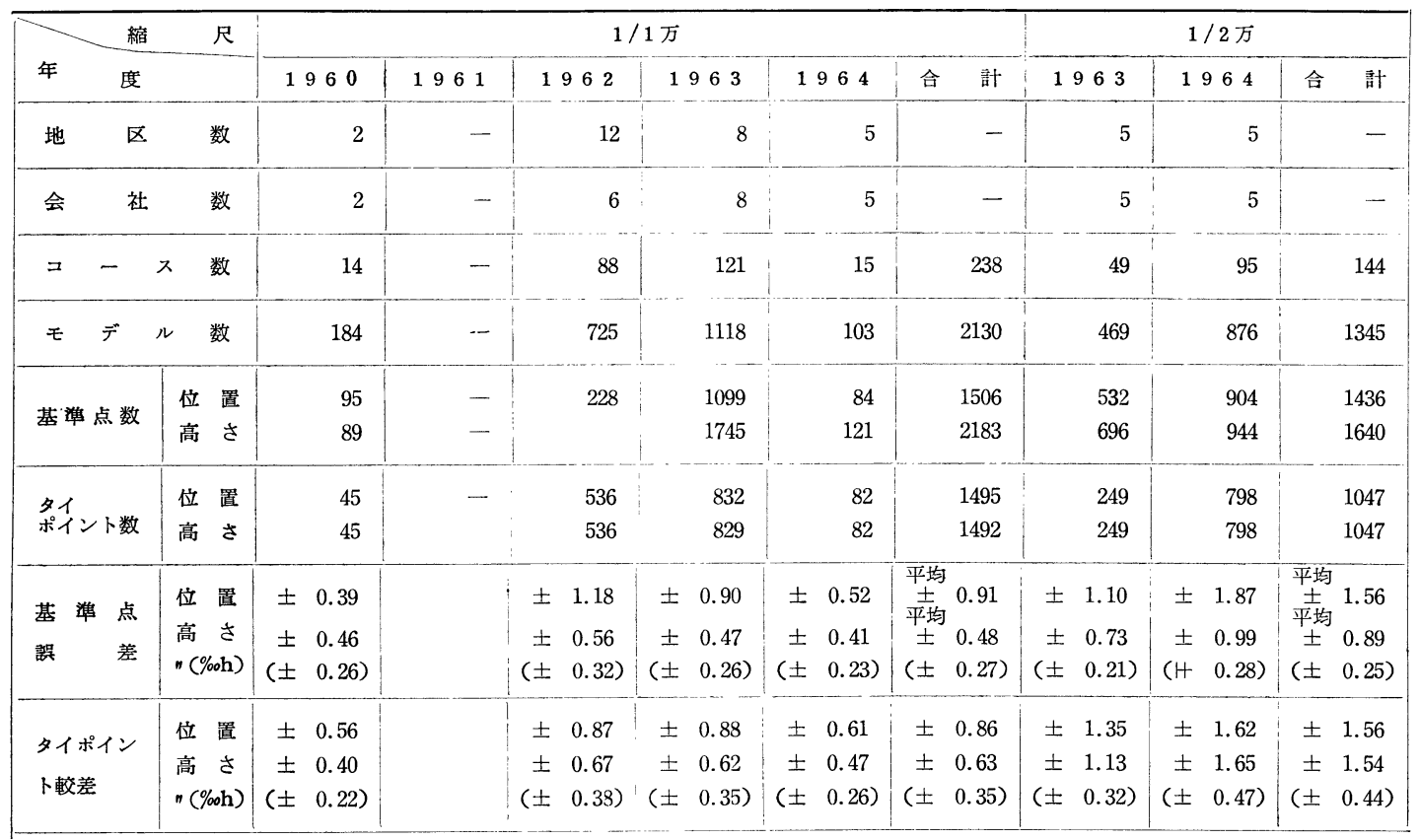

第 2 表 対空 標識と精度 写真縮尺 $1 / 10.000$

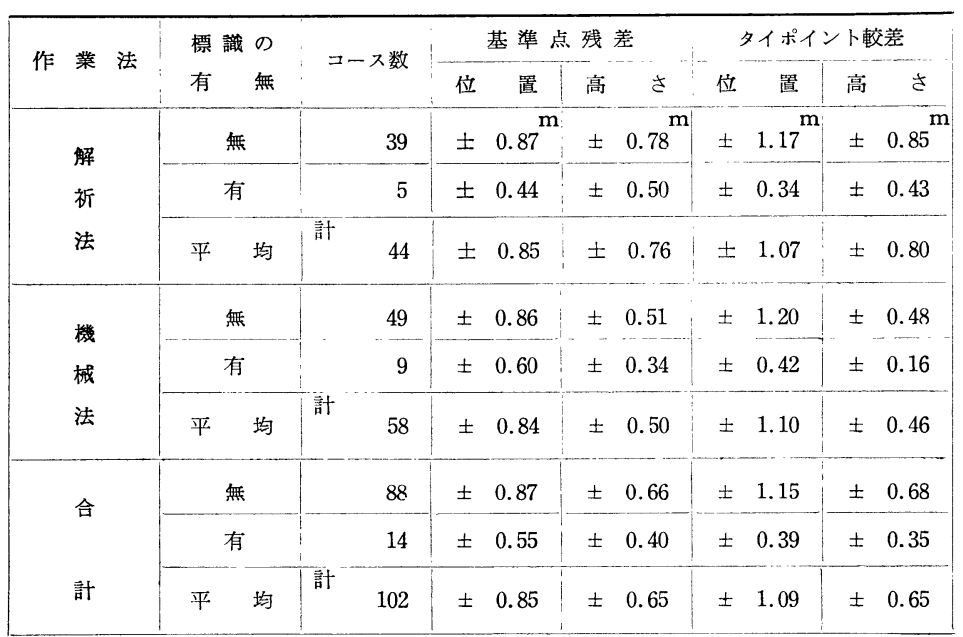

究開発が行われているのも日本の 特長で大いに敬意を払らべきであ るが，研究段階からの実用化に際 しては十分に慎重に移行すべきで あろら。

次にもら少し, 細かく分類して 検討して見よう。

\section{2-1 対空標識}

対空標識の有無により精度に差 があることは十分想像されるが， コース内の全点に標識が置かれた 場合，あるいは全然置かれなかっ た場合というのが少ないので敩密 な比較は困難なので 1 例として 1960年, 1962年の 2 年分について

のにどうしてこんなに悪いのかこの質問がしばしばな されている程である。

しかし大学や研究所での研究テストワークではなく コマーシャルベースでの大量作業の結果として第 1 表 のような数值が得られることは無視できない事実であ る。これについては最初の年のテストケースの場合が よく，またその後も段々よくなってきている傾向から 見て，大量作業を行った際の工程管理に問題があった のではないかとは十分考えられることであろら。

従来空中三角測量の精度については諸外国とは逆に

日本では，国土地理院でさしろ低く評価されていたの もこのような実績によるのである。各会社で種々の研
の統計をとって見ると第 2 表のよらになる。

第 2 表では一応解析法と機械法とにも分けて見た が，いずれの場合にも中等誤差に50\%あるいはそれ以 上の差があり，対空標識の効果は明かである。このデ 一夕等に基づき, 以後の作業では部分的にでもつとめ て対空標識を設置するようにしているので, それ以後 のデータからは標識の有無による精度の比較は困難て あり,ここでは省略する。

\section{2-2 作業法による差}

解析法と機械法とによる差よりは同じ機械法でも図 化機の種類や標定方法の差, 写真の質や, 個人差の方 が大きいと考えられるが，いろいろ議論の対象になっ 
た問題なので一応第 3 表にその比較を示す

この第 3 表では機械法, 解析法ともそれぞれいろい ろな機械や方法のものを含んでいるので, 正確な比較 とはいえないが，この表から見る限りでは解析法の場 合機械法に比ベ平面位置は基準点，パイポイント共に 10\%〜 $5 \%$ 程度精度がよく，逆に高さは10\% 20\%精 度が落ちるようである。

第 3 表 解析法と機械法

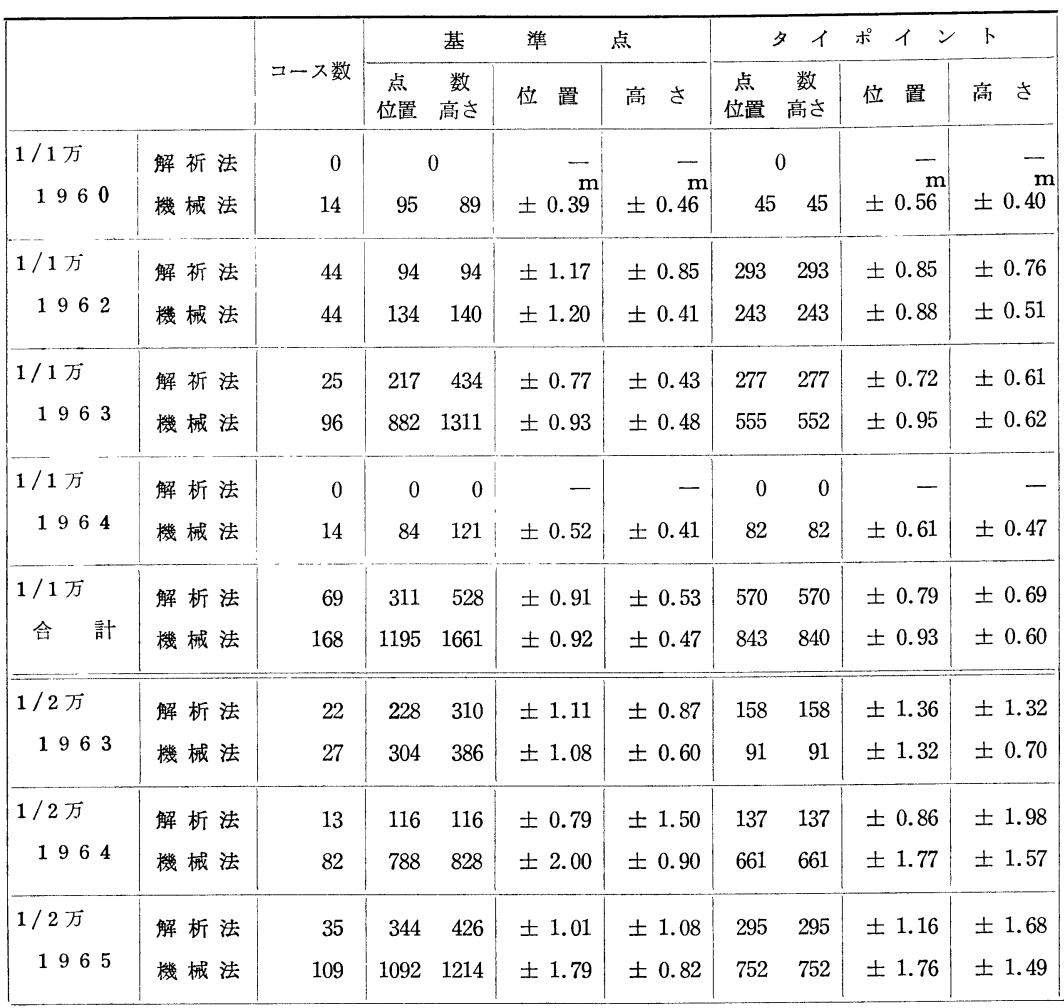

基準点の条件，および個人差等があってはっきりした ことはなかなか出ないが，解析法を採用している会社 と機械法を使用している会社との精度の差が，機械法 同士，解析法同士の会社の間の精度差よりも大きいか 小さいかは, 前節の解析法と機械法との差とも関連し て興味が持たれるので第 4 表にまとめて見た。ただし 第 4 表では計算の簡略化のため, 中等誤差の重量に基 準点の数でなく，コースの 数をとって計算した。

第 4 表の各社のデータの 総平均は第 1 表の各年ごと のデータの総平均に相当す るものである。第 4 表で括 弧に入っているのはデータ が 1 地区だけで少ないため 信頼度の低いもので, 従っ て例えば $\mathrm{E}$ 社の精度が特に よいことはこれだけではい い切れない。

まだンダーラインして あるのは昭和 40 年度の規格 によると不合格になるもの で，不合格の多いのは最近 の精度が向上してきて規格 も少し高められているため でもある。

この表からは基準点, タ イポイントの各縮尺での位 置と高さについて総合的に 特によいとか悪いとかいら

この原因として考えられるのは機械の精度や計算方 法ではなく，実体観測でえらんだ点を単眼コンパレー ターで測定しているための誤差ではなかろうか。機械 や計算方法によるものであれば平面位置の精度も悪く なる筈であろら。

単眼コンパレーターの場合, 平面位置は左右写真上 で実体視によらず別々に測った值の平均をとることに なるが，高さはそのX座標值の差をとっていることを 考えると上のような精度の差の説明がつけられるよう でもある。

この推論が正しいかどらかは国土地理院で購入した ステレオコンパレーターの結果を待って検討しなけれ ばならないが，現在日本で多く使われている単眼コン パレーター万式の解析写真測量にとって是非解明した い問題であろら。

\section{2-3 作業機関による差}

作業機関ごとの差も，使用機械，標定方法，地形や
会社は見当らないが，個々のデータ例えば基準点の位 置の精度についてはかなり会社間でバラッキがある。 これ以上は使用図化機, 作業方法（解析法, 機械法 等)などの他土地, 基準点の条件, 作業年度等をもあ わせ考えて検討すべきであるが，ここでは省略する が，各社間の精度のバラッキの方が解析法と機械法と に分けた場合の精度の差よりもむしろ大きいようであ る。

\section{§3. 空中三角測量の精度分析}

前節は国土基本図の成果として納品されたものにつ いての精度で，いわば「よそ行き」の結果である。し かし実際の工程では種々の理由で捨てられた基準点 や，パスポイントああり，改算がくりかえされたこと もある筈である。これらの捨てられたデータすなわち スケマホン教授のいら「かみくずかごの中のデータ」 を検討することも再測率の推定や「なまの精度」の計 
第 4 表 作業機関による精度の差

\begin{tabular}{|c|c|c|c|c|c|c|c|c|c|c|c|c|}
\hline 機 & 関 & 名 & A & B & C & D & $\mathrm{E}$ & $\mathrm{F}$ & G & $\mathrm{H}$ & I & 均 \\
\hline \multirow{2}{*}{$1 / 1$ 万 } & $\begin{array}{l}\text { 基 } \\
\text { 点 } \\
\text { 点 }\end{array}$ & $\begin{array}{ll}\text { 位 } & \text { 置 } \\
\text { 高 } & さ\end{array}$ & $\begin{array}{l} \pm 0.73^{\mathrm{m}} \\
\pm 0.53\end{array}$ & $\begin{array}{r}\mathrm{m} \\
( \pm 0.92)^{\mathrm{m}} \\
( \pm 0.51)^{2}\end{array}$ & $\begin{array}{l}{ }^{\mathrm{m}} \\
\pm 0.85^{3}\end{array}$ & $\begin{array}{l}{ }^{\mathrm{m}} \\
\pm 1.13 \\
\pm 0.38\end{array}$ & $\begin{array}{l}( \pm 0.41)^{\mathrm{m}} \\
( \pm 0.33)^{\prime}\end{array}$ & $\begin{array}{l}{ }^{1}{ }^{\mathrm{m}} \\
\pm 0.69 \\
\pm 0.68\end{array}$ & $\begin{array}{l}{ }^{\mathrm{m}} \\
\pm 1.64 \\
\pm 0.61\end{array}$ & $\begin{array}{l}( \pm 0.46)^{\mathrm{m}} \\
( \pm 0.44)\end{array}$ & \begin{tabular}{l|}
$\mathrm{m}$ \\
-
\end{tabular} & $\begin{array}{l} \pm 0.50^{\mathrm{m}} \\
\pm 0.41\end{array}$ \\
\hline & $\begin{array}{l}\text { 夕イ } \\
\text { 1ㅊ } \\
\text { ポト }\end{array}$ & $\begin{array}{ll}\text { 位 } & \text { 置 } \\
\text { 高 } & \text { さ }\end{array}$ & $\begin{array}{l} \pm 0.73 \\
\pm 0.53\end{array}$ & $\begin{array}{l} \pm 0.93 \\
\pm 0.89\end{array}$ & $\begin{array}{l} \pm 0.82 \\
\pm 0.42\end{array}$ & $\begin{array}{l} \pm 0.71 \\
\pm 0.47\end{array}$ & $\begin{array}{l}( \pm 0.81) \\
( \pm 0.44)\end{array}$ & $\begin{array}{l}( \pm 0.87) \\
( \pm 0.79)\end{array}$ & $\frac{ \pm 1.49}{( \pm 0.99)}$ & $\begin{array}{l}( \pm 0.72) \\
( \pm 0.56)\end{array}$ & - & \\
\hline \multirow{2}{*}{$1 / 2$ 万 } & $\begin{array}{l}\text { 基 } \\
\text { 蕉 } \\
\text { 点 }\end{array}$ & $\begin{array}{cc}\text { 位 } & \text { 置 } \\
\text { 高 } & \text { さ }\end{array}$ & $\begin{array}{l} \pm 1.17 \\
\pm 0.97\end{array}$ & $\begin{array}{l} \pm 0.97 \\
\pm 1.26 \\
\end{array}$ & $\begin{array}{l}( \pm 1.19) \\
( \pm 0.67)\end{array}$ & $\begin{array}{l} \pm 1.03 \\
\pm 0.81\end{array}$ & $\begin{array}{l}( \pm 0.92) \\
( \pm 0.35)\end{array}$ & $\begin{array}{l} \pm 3.05 \\
\pm 0.85\end{array}$ & - & - & $\begin{array}{l}( \pm 1.04) \\
( \pm 0.50)\end{array}$ & $\begin{array}{l} \pm 1.74 \\
\pm 0.99\end{array}$ \\
\hline & $\begin{array}{l}\text { 多1 } \\
\text { 1̀y } \\
\text { ポ下 }\end{array}$ & $\begin{array}{ll}\text { 位 } & \text { 置 } \\
\text { 高 } & さ\end{array}$ & $\begin{array}{l} \pm 1.78 \\
\pm 1.63\end{array}$ & $\begin{array}{l} \pm 1.24 \\
\pm 1.80\end{array}$ & $\begin{array}{l}( \pm 2.12) \\
( \pm 1.46)\end{array}$ & $\begin{array}{l} \pm 1.37 \\
\pm 1.12\end{array}$ & $\begin{array}{l}( \pm 1.28) \\
( \pm 0.43)\end{array}$ & $\begin{array}{l} \pm 1.67 \\
\pm 1.73\end{array}$ & - & - & $\begin{array}{l}( \pm 1.33) \\
( \pm 0.44)\end{array}$ & \\
\hline
\end{tabular}

算に必要なことであろうと考えられるので，39年度の 受注会社中の数社（国際航業, 国内航空, 写真測量所 大洋航空，日本総合）に打願いして，捨てられたデー タやその他の追加計算等をまとめていただいた。その 結果を以下に簡単に紹介しておこう。

\section{3-1 一次補正と二次補正}

1 次と 2 次の等角写像变換による精度を 1 コースだ けであるが比較して見た。その結果は第 5 表のとおり である。写真縮尺は約 $1 / 25,000$ ，調整に使用した基 準点は18点である。

2 次補正は 1 次補正にくらべ，中等誤差最大誤差共 約 $1 / 2$ になっている。ただし，a，b欄で最大誤差を 示した点は同じ点ではない。（ $\mathrm{a} ， \mathrm{c}$ 欄は同じ点であ った）ここで興味があるのは、欄のようにして計算し

第 5 表 1 次補正と 2 次補正

\begin{tabular}{|c|c|c|c|c|}
\hline & 1 次補 正 & 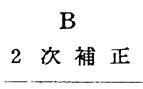 & 1 次補正一補正 & $\sqrt{\frac{D}{a^{2}+c^{2}}}$ \\
\hline 中等誤差 & $\pm 2.01 \mathrm{~m}$ & $\pm 1.09 \mathrm{~m}$ & \pm 1.85 & \pm 2.15 \\
\hline 最大誤差 & $4.58 \mathrm{~m}$ & $1.88 \mathrm{~m}$ & 4.18 & $\pm 4.6 \mathrm{~m}$ \\
\hline
\end{tabular}

た值が $\mathrm{c}$ 欄の值に非常に近いことである。これはあた かも $\mathrm{a}$ 欄と c 欄とを互に独立として

$$
\mathrm{b}=\mathrm{a}+\mathrm{c}
$$

すなわち

$$
\begin{aligned}
& 2 \text { 次補正值 }=1 \text { 次補正值 }+(2 \text { 次補正項 }- \\
& 1 \text { 次補正項 })
\end{aligned}
$$

と考えた場合に近い結果が得られたことになる。これ は等角写像変換の直交性に負ら所があると思われる。

この1コースだけの結果から断定的なことをいらの は避けるべきであるが，過去の経験等も総合して， 2 次補正は 1 次補正の誤差を約半分にすると考えられる ようである。

\section{3-2 点検点の精度}

ここで点検点といらのは調整計算に用いられなかっ
た点で，その内に最初は調整に用いられたが誤差が大 きいため最終的に除外された点をかなり含んでいる。 ただし観測だけは行われたが全然計算を行わなかった 点は含まれていない。その結果は第 6 表のとおりであ る。

第 6 表からすぐ気付かれる事柄は次の通りである。

（1）非常に大きい誤差まで点検点の誤差として報道さ れた場合がある。これは多分点の誤認と思われる が，誤認か否かの判断基準が確立していないようで ある。例えば $\mathrm{G}$ 行の最大誤差 $101.31 \mathrm{~m}$ は点検点だ けから計算した入の 3 倍よりも大きいが，これは殆 ど確実に点の䛊認であったといえる。このような場 合, 例えば $3 \lambda$ 以上の䛊差は再検討のうえ，䛊認点で あれば捨てるといらようにはっきりした基準を作る ベきであろう。

(2) 逆に捨てている可能性も考えられる。 例えば F 検定を適用して見ると D行と F 行との高さについては基準点と点検点と の中等誤差は $1 \%$ 危険率でも同じもの であると推定されるし，作業規定の精度 にも殆ど合格している。さらに第 6 表中 の採用された基準点での最大䛊差と点検点での中等 誤差とを比べて見て両者にあまり差のない場合もあ る。点検点の中に含まれている明瞭な䛊認点を取去 って考えればこのことはさらにはっきりするであろ 5。

以上の(1)，(2)を通じて, 基準点に一定以上大きい俁 差が生じた場合の取扱いに一貫した明瞭な方針が欠 计ているよらに見受けられる。

(3) 採用，不採用の点数をくらべると採用点数の約 2 割の点検点がある。この中には勿論初からの点検点 もあろらが（例えばA行の多数の標高点検点は簡易 水準点を利用した）その大半は精度不良による不採 用点, あるいはその場合に備えた予備点であろらと 推定される。 
第 6 表 点検 点 $の$ 精 度

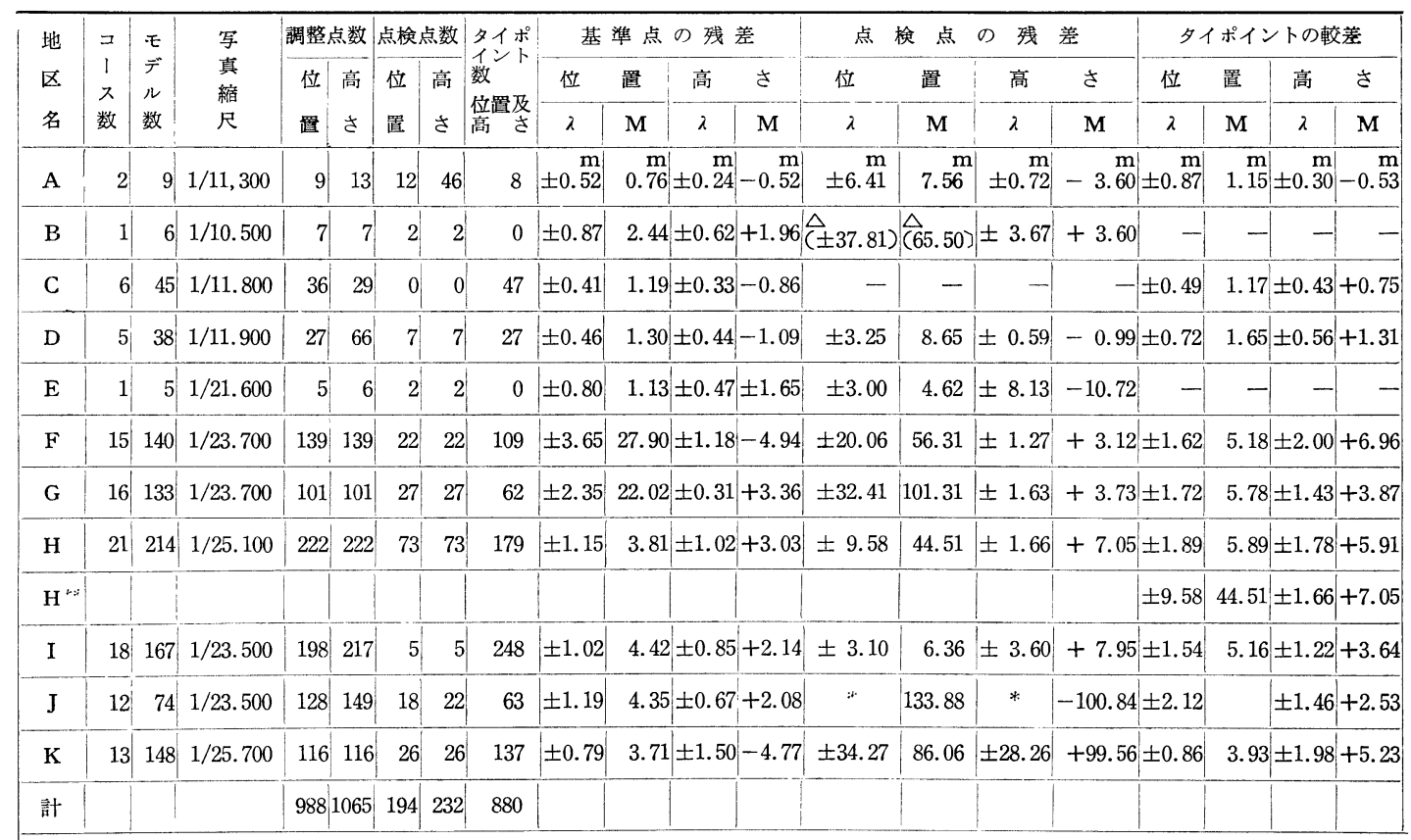

注 1 . 入 は中等誤差, M最大誤差 2 . *印の欄は $10 \mathrm{~m}$ 以上の 誤差が多かったので計算してない。3．H の行は不採用となった

正規分布の場合, 誤差の大きい方から 2 割を捨て る限界は約 $1.6 \lambda$ であり，かなり危険な棄て方であ る。

ところが第 6 表で中等誤差と最大誤差（採用され た誤差の上限）とを比べて見ると $2 ， 3$ の例外を除

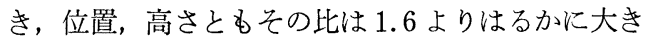
い。従ってこれらの䛈差は正規分布からは大きく外 れた分布をしているとも見られる。この原因の大半 は現地でか室内でかは分らないがともかく点の誤認 にあると推定される。しかも 2 割近い誤認というの は精度上も経済上も重大な問題である。

この表から国土基本図，空中三角測量の最大の問 題点は, 機械法か解析法か等の区別よりはむしろ, 如何に誤なく正確に基準点を写真上に表示し, 確認 するかにあるといらことが，かなりはっきり認めら れると思う。（第 6 表中解析法によるのはK行だけだあ る)

上とは逆に $\mathrm{A}$ 行, $\mathrm{B}$ 行なぞ1.6入程度の誤差の点ま で全部棄ててしまっている。これは誤差の大きい点 は竦てるといら安易な習慣がついているためではな いかと思われるが，これもはっきりした基準によっ て行らべきであろう。

（4）棄てられた点の内誤認によると思われる点を除 き（データが手許に揃ってないので最大䛊差だけ を裹てた）採用不採用全部の点の誤差を計算して見
タイポイントの誤差を示す。 ので括弧に入れた。

4. $\triangle$ 周の蘭は数值に疑問がある

た。これはいわば「なまの精度」であるがその結果 は第 7 表のとおりで，採用された点とくらべ，数倍 の誤差を持っている。この中にはまだ誤認点が含ま れていると思われるが, 街路を一つ間違えたといら ような䛊認は別として, 基準点の位置の 確認誤差 が, 2 〜 メートル程度の場合には, はっきりとそ の事実が指摘できない限り誤認として捨てることは 許されず，むしろ基準点の確認をも含んだ空中三角 測量の精度がそれだけしかなかったと考えなければ ならない。上記のように国土基本図の成果では棄て るべきでない点を捨てていることも考えられるが， このなまの精度をも考え合わせると, 実際の鿁差は $1.5 \sim 2$ 倍程度と見る方が安全であろう。（勿論基 準点確認の誤差も含めて)

\section{§4. 図化の精度}

図化検査は中間検査と最終検査の 2 回, それぞれ抽 出検查を行っている。抽出量は各工程ごとに多少ちが らが大体10～20\%程度でそれぞれ室内の機械検査と図 化検査に分れている。

検査の細かい内容は年度によっても多少らがうが， 大体次のような項目について, 精度, 脱落, 誤記等を しらべる。

展 開 \{方眼 (図郭)


第 7 表なまの精度

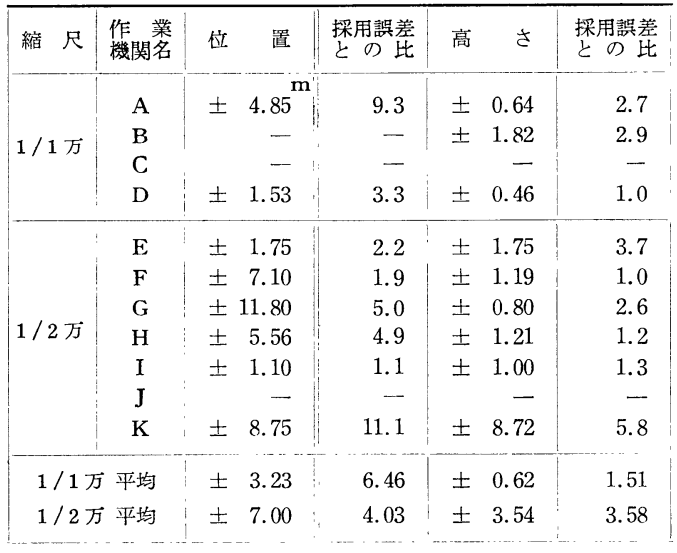

図化平面図形 $\left\{\begin{array}{l}\text { 線状地物 } \\ \text { 家屋 }\end{array}\right.$

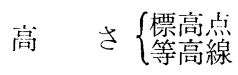

特に展開を重視しているのは過去の実例から見て後 述のように展開の致命的䛊差が非常に多いからであ る。

個々の検査での結果誤りが発見された場合には次の 3 種に分外る。

$\mathrm{E}_{1}$ 致命的な誤差（描き值しを必要とする程度）基 準点の展開位置の誤差, 標定の誤り，大きい地物 の脱落, 線状地形の大きい歪, 接合不良等。

$\mathrm{E}_{2} \mathrm{E}_{1}$ に次ぐ重大な䛊差（訂正加描によって修止: できる程度) 小さい道路の誤記, 脱 落, 地類の誤り, 家屋の脱落, 地名 の誤記，接合の小さい不合等。

$\mathrm{E}_{3}$ 小さい誤差 画線のかすれ,家屋や 真幅道路の形状不良, 地名注記の位 置不適等の小さい誤差。

検査結果を集計して(この時誤りのな かった合格件数も数光ることが大切であ

る）次のような A B Cの判定を下す。

判定A 合格

$$
\text { 基準 }\left\{\begin{array}{l}
\mathrm{E}_{1} \text { がない } \\
\mathrm{E}_{2} \text { が5\%以内 } \\
\mathrm{E}_{3} \text { が } 20 \% \text { 以内 }
\end{array}\right\} \text { 条件をすべて充す場合 }
$$

判定B 条件付合格

$$
\text { 基準 }\left\{\begin{array}{l}
\mathrm{E}_{1} \text { がない } \\
\mathrm{E}_{2} \text { が20\%以内 } \\
\mathrm{E}_{3} \text { が50\%以内 }
\end{array}\right\} \text { 条件をすべて充す場合 }
$$

判定C 不合格

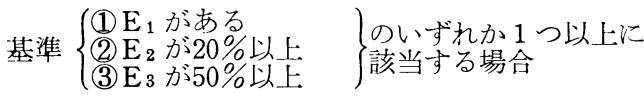

これは大体の目安であって，実際にはA B Cをさら
に 2 階級に分け, $\mathrm{Aa} \mathrm{Ab} \mathrm{Ba} \mathrm{Bb} \mathrm{Ca} \mathrm{Cb}$ として判定 する場合もある。

判定後の処置は次のとおりである。

判定Aの場合

原則としてそのロット全部を合格とする。ただし検 查の際発見された愦や，その他の指示事項について は手入れする。

判定Bの場合

ロット全部について該当事項を再調査（その事項に ついては不合格である）する。例えば 5 面の中から 1 面抽出して，その等高線の精度が悪ければ 5 面全 部の等高線の描き值しをしなければならない。「た またまその 1 面だけが悪かったので他の 4 面は大丈 夫だ」との抗弁が時々なされるが，これは抽出検査 の意義を理解していない言分である。もしそらなら ば逆に 1 面だけ合格の場合でも他の 4 面は不合格と いら可能性もあるわ忛で，そもそも5面のら号 1 面 だけが著しく他と異質であるといらならば抽出検査 は成立たないし，そのような場合にはをしろ全数検 査すべきであろう。

判定Cの場合

娭査途中でも判定 C と結論が出れば值ちにロット全 部について全面的に作業のやり直しである。ただし 事情によっては一部分生かすこともあり得る。

第 8 表は昭和 39 年度㘠化検査の概況で第 2 図にその

\begin{tabular}{|c|c|c|c|c|c|}
\hline 作 業 & & 類 & $1 / 2.500$ & $1 / 5.000$ & $1 / 2.500$ 骨格図 \\
\hline 地 & & 数 & 5 & 10 & 9 \\
\hline \multicolumn{3}{|c|}{ 総 困化 量（四面数） } & 74 & 287 & 120 \\
\hline 検 查 量 & & 間 & $11(15 \%)$ & $43(15 \%)$ & 一 \\
\hline （図面数） & & 終 & $10(14 \%)$ & $34(12 \%)$ & $15(12 \%)$ \\
\hline
\end{tabular}
総合判定の結果を示した。

第 8 表図化検査の概況

第 3 図では中間検査の成績は平均 $\mathrm{Bb}$ 程度であっ て，これが最終検查では約一階級よくなり平均 $\mathrm{B}$ a 程 度になっている。（ただし骨格図は最終検査しか行ってい ない）これは百点満点にすると約 10 点の向上に相当す ると考えられる。また最初の成績から 2 階級上げた例 はなく，最初の図化が大切なことも分る。

なお各項目ごとの不合格（判定C）は第 3 図のと㧤 りである。

第 3 図でも分るよ5に展開不良によるものが不合格 り半分近い。第 3 図中の地物とは線状物体, 地類, 家 屋等をまとめたもので，高さには独立僄高点と等高線 を含んでいるので，実際には展開による不合格のウェ イトは半分上り大きい。に，最終検查で増加してい 
第 2 四 図化検査成績
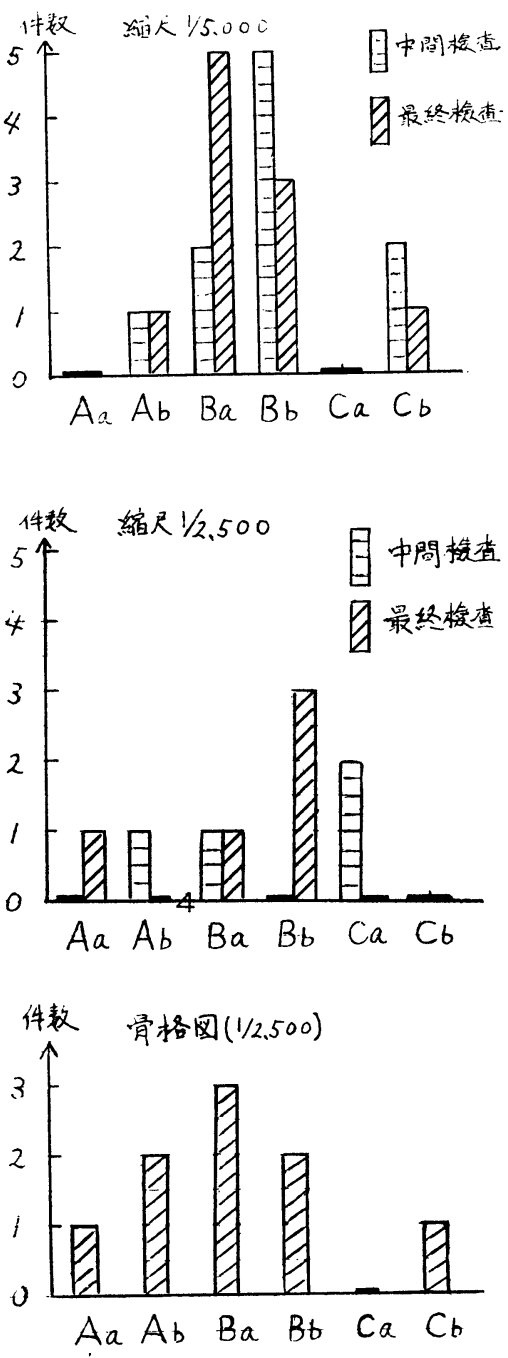

る傾向にあるが,

これは中間検査後他の図化内容は手入が行われる

第 9 表 図化検査成績表

\begin{tabular}{|c|c|c|c|c|c|c|c|c|c|c|c|c|c|}
\hline \multirow{2}{*}{\multicolumn{2}{|c|}{ 成 績 }} & \multicolumn{6}{|c|}{$1 / 2.500$} & \multicolumn{6}{|c|}{$1 / 5.000$} \\
\hline & & $\mathrm{Aa}$ & $\mathrm{Ab}$ & $\mathrm{Ba}$ & $\mathrm{Bb}$ & $\mathrm{Ca}$ & $\mathrm{Cb}$ & $\mathrm{Aa}$ & $\mathrm{Ab}$ & $\mathrm{Ba}$ & $\mathrm{Bb}$ & $\mathrm{Ca}$ & $\mathrm{Cb}$ \\
\hline \multirow{2}{*}{ 展 } & 中間 & $3^{1}$ & 1 & 0 & 0 & $0^{4}$ & $0^{19}$ & 5 & $1^{\text {件 }}$ & $0^{\text {件 }}$ & $1^{\text {件 }}$ & $1^{\text {件 }}$ & $2^{\text {件 }}$ \\
\hline & 最終 & 4 & 0 & 0 & 0 & 0 & 1 & 1 & 1 & 3 & 0 & 0 & 5 \\
\hline \multirow{2}{*}{ 地 } & 中間 & 1 & 1 & 0 & 0 & 0 & 1 & 5 & 1 & 3 & 1 & 0 & 0 \\
\hline & 最終 & 2 & 1 & 0 & 2 & 0 & 0 & 3 & 4 & 2 & 1 & 0 & 0 \\
\hline \multirow{2}{*}{ 高 } & 中間 & 1 & 0 & 1 & 1 & 0 & 0 & 0 & 1 & 3 & 3 & 0 & 3 \\
\hline & 最終 & 2 & 0 & 0 & 0 & 0 & 0 & 0 & 5 & 1 & 3 & 0 & 1 \\
\hline \multirow{2}{*}{ 総 } & 中間 & 0 & 1 & 1 & 0 & 2 & 0 & 0 & 1 & 2 & 5 & 0 & 2 \\
\hline & 最総 & 1 & 0 & 1 & 3 & 0 & 0 & 0 & 1 & 5 & 3 & 0 & 1 \\
\hline
\end{tabular}

第 3 図 不合格件数

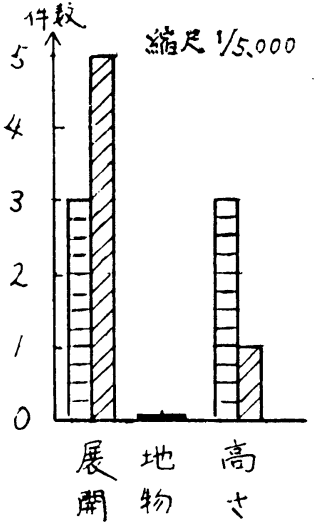

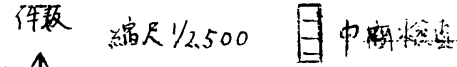

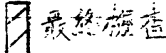

が，展開は初にやったまま中間で再点検されていない ので, 2 回目の最終検査で別の図面が抜き取られた際 また新らしく発見されたものと思われる。また眓化検 査成績の内容は第 5 表のとおりで，この表から見ると 展開は極端によいものと極端に悪いものが多い,つま りムラが大きいことが推定される。

なお図化の機械検査の昭和 39 年度と昭和 37 年度の分 は第 10 表のと扤りである。この中 39 年度の分について は30〜 50個所について検査結果で家屋の精度をのぞい てはいずれも作業規程の許容誤差内に納まっている。 第 10 表中昭和 37 年度の機械検査結果は統計の方法が多 少ちがったため，家屋の精度がなく，また線状物体を 鉄道，道路等に組分したので数值が 1 つに限定されて いない。さらに市街地周辺，農耕地に分けて統計をと っている。

むすび 国土基本図の検査は限られた人員で短期間 に室内機械検査と現地検査を行わなければならない ので, 能率的効果的な検查方法をさらに研究すべきで ある。以上のデータはこの仕事の間にまとめたため時 間的制約も受け，不十分な点や物足りない個所も多 w。

またこれだけのデータから結 論を出すのは早急にすぎるであ ろらが，せっかくの資料であ クまたこれをまとめる過程で 気付いた事柄をのべて将来の参 考としたいといらのが，この論 文の目的である。広く各方面か らの御批判が得られれば幸いて ある。 
第 10 表 図化の機械検査の結果

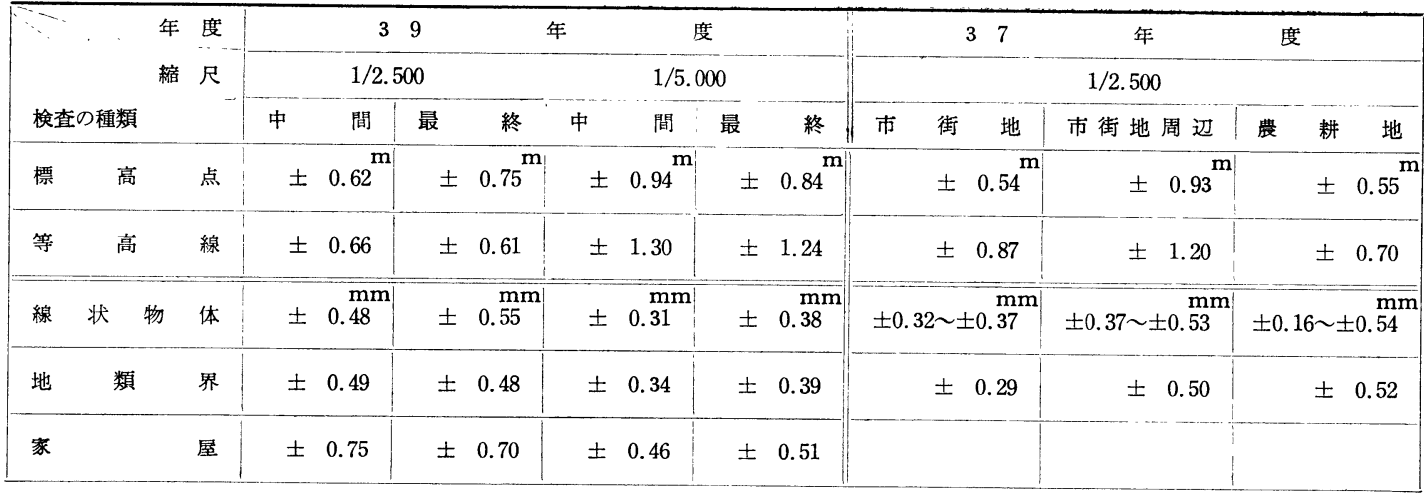

\section{考考文献}

（1）平井 雄 国土基本図空中写真の検査結果について (英文)

国土地理院報告 Vol. 7 No. $2-4$ p.89

$-102$

（2）平井 婎 国土基本図空中写真の検査について 写真測量 Vol. 1 No. 2 p.78-84

（3）尾崎幸男 国土基本図における精密空中三角測量の概 要 (英文)

国土地理院報告 Vol. 9 No. $1 \sim 2$ p. 22 $-27$
（4）鈴木利男 垣下精三，盛，憲一

国土基本図における精密空中三角測量の結 果 (英文)

国土地理院報告 Vol. 9 No. $1 \sim 2$ p. 28 $-38$

（5）中村六郎 空中写真の検查について

測量 1965年 4 月号 p.17-23

（6）中野尊正 国土基本図

科学 Vol. 6 p.308-311

\section{レスポンス函数と写真測量}

\section{平井雄}

空中写真測量を特別な興味の対象として取りあげ，被 写体からはじまり, 最終的な測定結果にいたる情報伝達 の過程を, いわゆるレスポンス函数と呼ばれる集現方法 で記述した論文が, ここ数年来, 光学や写真関係の雑誌 で目につくようになって来た。電気の方でなじみの深い レスポンスといった考え方が光学に導入されてから15年 近く，すでに古典的な概念になりかかっているが，純粋 な光学以外の応用分野で実用的な概念になったのはよう やく緒についたといったところであろらか。その実用化 の第一歩として, 空中写真が取り上げられたのは故のな いことではない。写真を使って定量的な測定を行うとい ら点にかけては, 写真測量は光学一写真系に対して最も 厳密な要求をもっており, 判読に使う場合でも非常に微 妙な複写体の色調, 形状の差を差として表わすことが要 求されている。しかも, 写真は何千米といら高い処で,
高速度で動いている飛行機から撮影され，その上，被写 体のコントラストは非常に狭い巾の中に王縮されている のであるから, 空中写真測量の光学一写真系を多少なり とも改善しょうとするためには, 必要な情報伝達の流れ についての本質的な理解が要求される訳である。

幸いなことに，このレスポンス函文については，日本 語の秀れた解説書がある。即ち,

レンズ性能研究委員会 (カメラ工業技術 研 究 組 合)

編「写真レンスとレスポンス函数」がそれである。 その他では Applied Optics に載った I.T.C.の Hempenius 氏の論文 ( 2 年程前) が分りよい。

最近のものでは Photographic Science and Engineering (Nov.-Dec. 1965) の Charman 氏尤よび Olen 氏の「Image Quality Criteria for Aerial Camera Systems」や Photogrammetric Engeneering (Jan. 1966)の Barraw 氏の「Microdensitometev Transfer Function Correction」等があるが, 後者 は多少分りにくい。 